\title{
Trust and commitment within franchise systems: An Australian and New Zealand Perspective
}

\author{
Mr. Owen Wright BCom MAppL \\ Lecturer in Marketing \\ Griffith Business School \\ Griffith University \\ Brisbane, Australia, 4111 \\ Telephone: +61 737353557 \\ Fax: +61 737357126 \\ Email: O.Wright@griffith.edu.au
}

Mr Owen Wright is a Lecturer in the Department of Marketing at Griffith University. His industry experience includes marketing management roles within the franchising sector and as a consultant to franchisors. Owen is an active member of the Asia Pacific Centre of Franchising Excellence, International Society of Franchising, the Australian and New Zealand Marketing Academy and the European Marketing Academy.

His research focuses on expansion models in a mature Australian franchising sector. As a result, he has published his research in international academic refereed journals including the Journal of Marketing Management, Journal of Brand Management, and the Australasian Marketing Journal. Owen co-authored the Franchising Australia Surveys 2006 and 2008. He teaches franchising, channel management and retailing in the Griffith Business School at both undergraduate and postgraduate levels.

\author{
Mr. Anthony Grace BCom BMkt (Hons) \\ Griffith Business School \\ Griffith University \\ Brisbane, Australia, 4111 \\ Telephone: +61 733821404 \\ Fax: +61 733821404 \\ Email: A.Grace@griffith.edu.au
}

Mr Anthony Grace achieved first class honours in 2007 and conducted research for the Asia-Pacific Centre for Franchising Excellence (www.griffith.edu.au/apcfe). His research focused the sociological aspects of the franchising industry. 


\begin{abstract}
Purpose - Although research in franchising is currently experiencing an advancement in the investigation of behavioural attributes, the motivators and perceptions of participants within this partnership, the key variables of trust and commitment a key to successful business relations requires further insight. The purpose of this paper is to extend the idiosyncratic dynamics of the franchisor-franchisee relationship and the influence of such constructs from a distance perspective. Seminal work on relationship marketing (e.g. Morgan and Hunt, 1994) forms the foundation in the development of The Franchising Relational Dynamics Model posed within this paper.
\end{abstract}

Design / Methodology / Approach - This paper adopts a qualitative, case based approach of four Australian retail franchises with holdings in New Zealand. In-depth interviews were conducted with 20 franchisee' to derive perceptions on trust and commitment currently experienced within the franchise relationship to inform the resultant findings.

Findings - Key findings suggest trust and commitment are limited or non-existent within franchise systems if the provision of consistent, transparent communication is absent or minimal, increasing the propensity for dysfunctional agent based behaviour. Three major antecedents for success of a franchise system exist: goal congruence, organisational culture, and communication. Minimal levels of commitment and trust exist where distance affects the stated antecedents.

Research limitations / implications - This research is exploratory with the findings providing an imperative for further investigation in the management of human factors within franchise systems as opposed to transactional-based foci in many current studies. Theoretical development adopting a relationship marketing focus from a distance perspective rather than the transaction-based approach of a single country adds to existing research. This paper is limited to analysis of franchisees perceptions. Future research should look at both franchisor and franchisee perspectives.

Originality / value - Research of perceptions of individual franchisees, trust and commitment within the franchise relationship is limited within the Asia-Pacific region. Findings of possible dynamic differences in the franchisor/franchisee dyad provide initial evidence advancing and informing both academic and managerial practice.

Keywords - Trust, commitment, franchising, relational governance

Paper type - Research paper 


\section{Trust and commitment within franchise systems: An Australian and New Zealand Perspective}

\section{Introduction}

Australia’s franchising sector, representing 14 percent of Australia's gross domestic product is rapidly evolving. Internationalisation strategies for this business structure a particular current focal point in management and marketing research (Frazer, Weaven \& Wright, 2008). Of the 1100 business format franchisors (and an estimated 71,400 units operating in business format franchises) identified in 2008, 67 percent favoured New Zealand as an international expansion destination (Frazer, Weaven, \& Wright, 2008). Fundamental to generating positive environments within an international franchise system is the implementation of strategies promoting franchising effectiveness. One potential strategy is the application and enhancement of trust to strengthen commitment between participants (Morgan \& Hunt, 1994).

In a typical franchise system format, the franchisor grants franchisees the opportunity to engage in a developed business concept, generally the provision of intangible assets, such as the brand name and trademark (Hunt, 1973). A franchise system is not only an economic system, but also a social system constituted of the participants often closely working together, sometimes developing a personal relationship (Etgar, 1978; Strutton, Pelton, \& Lumpkin, 1995). Consequently, the essential behavioural dimensions of commitment and trust that characterize a social system (Morgan and Hunt, 1994) are also characteristic of a franchise system.

Franchising scholars have studied behavioural dimensions of the franchise relationship to determine how it can be managed effectively (Dant \& Gundlach, 1999; Quinn \& Doherty, 2000; Spinelli \& Birley, 1996; Stern \& Reve, 1980; Davies, 2009) but there is a paucity of franchising research in the area of commitment and trust as 
defined in relationship marketing. As the success of any franchise system is largely influenced by the relationship between the franchisee and the franchisor (Nathan, 2000), it is important to identify contemporary issues and extend research that potentially relates to effective franchising relationships. Relational dynamics within retail franchise systems identified in this research attempt to extend insight for practitioners and academics alike.

Therefore, this study applies the KMV (key mediating variables) model as defined by Morgan \& Hunt (1994) to ascertain if it is appropriate in a franchise context. Hence, an exploratory qualitative approach, consisting of twenty face-to-face interviews with franchisees across four international retail franchise systems in Australia and New Zealand, informs the results within this paper. Probing questions developed via an interview protocol explored key elements of the franchising relationship. Important among these elements were those of trust and commitment were present and if they were present in relationship with the franchisor. Preliminary evidence supports the development of an extended conceptual model (see figure 2) providing new insights into franchising relationship effectiveness.

\section{Literature Review}

Lafontaine and Slade (1997) highlight agency theory as a motivation to franchise. An agency relationship involves one party (the franchisor) delegating work to another (the franchisee), whom conducts the work provided (Eisenhardt, 1989). Incentives and insurance are an important component for a franchisees under an agent-theoretic premise. Thus franchisors' efforts must align sales with the level of incentives provided (Lafontaine \& Slade, 1997). At present, research contextualising 
trust and commitment constructs within the franchise relationship is evident (Chiou, 2004; Davies, Lassar, Manolis, Prince \& Winnor, 2009; Harmon \& Griffiths, 2008). For example, Davies et al, 2009 argues trust as an integral attribute towards the acheivement of attaining franchisee compliance, goal congruence and resultant satisfaction within the franchise relationship. Further, the franchise relationship is characterised as interdependent; legally, economically and operationally (Chiou, 2004; Davies et al, 2009). However, vunerable situations often arise when perceived benefits are not acquired, with trust identified as essential factor aiding the reduction of vunerability and positively contributing to internal transparency and mutual responsiblity (Harmon \& Griffiths, 2004; Davies et al, 2009). However, current research remains, broad at best, with aformentioned studies lacking sectoral and distance dilenation (created by an international context).

Geographic variables contributing to the dysfunction of agent behaviour is a topic of interest. Since Castrogiovanni, Combs and Justis (2006) research, little investigation of trust and commitment within a long distance franchise relationship is evident. Moreover, trust and commitment constructs are fundamental to relationship marketing research. For example, Morgan and Hunt (1994), define relationship commitment, as an ongoing relationship between partners deemed important enough to exert maximum effort to sustain it. Therefore, dyadic trust requires mutual exchanges of confidence and integrity (Harmon \& Griffiths, 2008; Davies et. al. 2009). Theoretical outcomes from these studies provide positive correlation between key variables of relationship benefits and relationship commitment; shared values and relationship commitment; communication and trust; and, relationship commitment and trust, exists (Morgan and Hunt, 1994; Harmon \& Griffiths, 2008). Consequently, commitment and trust within channel relationships, often fraught with uncertainties, is 
an integral facet in promoting efficiency, productivity, and effectiveness. However, such findings are limited and provide an inadequate understanding of distance, as an antecedent to dysfunction, in the development of commitment and trust within the franchisor-franchisee relationship.

In addition, research investigating the link between intellectual capital and successful franchisor-franchisee relationships suggests trust, culture, incentives, and communication are important factors in structural capital to support a climate in aiding prosperous system development (Watson, Stanworth, Healeas, Purdy \& Stanworth, 2005). Intellectual capital works as a form of balance sheet assessing the full value of a company through its assets, including; Human Capital, Relational Capital, Competitive Capital, and Structural Capital (Laliaert, 2003 as cited in Watson et al, 2005). In particular, trust from a franchisee is measured by how much information and data is shared with the franchisor creating symmetrical communication channels (vis-a-vis knowledge exchange) and this is regarded as important in building trust worthy relationships (Watson et al, 2005; Chiou, Hsieh \& Yang, 2004). Again, the question remains unanswered if this link is synonymous when applied in a long distance context (created through international borders) within franchise systems.

Cross-cultural studies highlight a positive correlation between trust and intrasystem satisfaction if bilateral participative communication exists. For example, Berndts’ 2004 South African study of franchisee-franchisor relationships, revealed 54.2\% of the agents (franchisees) believed a positive relationship existed, a result of high quality support upon request and any dissonance regarding the business system addressed in a timely, transparent manner by the principle participant (franchisor). Further, Australian research investigating the franchisor franchisee relationship poses 
similar findings. In the Franchising Australia Survey 2006, 211 franchisors questioned on how well the franchisor and franchisee trust each other, 166 respondents agreeing or strongly agreeing. Further, 182 of 211 respondents agreed or strongly agreed this bond as positive if trustworthy of the other participant. Similar trends continue in later studies (Frazer, Weaven \& Wright, 2006, 2008; Frazer, Weaven \& Bodey, 2010). Moreover, if the principal provides consistent, transparent communication to the agent dysfunctions within the relationship are minimised. Findings revealing a large majority of participants concurring co-operative communication aids in closer goal congruence and allows in the creation of positive feelings within the intra-system (Weaven, Frazer \& Giddings, 2010). Most significantly, the facilitation of knowledge transfer is a crucial precursor in the achievement of a trust and a resultant harmonious amalgamation (Koza \& Dant, 2007). Pizanti and Lerner (2003) explain if this lack of trust exists, increasing the likelihood of franchisee disconnection. Thus, there is a direct correlation between the role of trust in franchise organisations, compliance and satisfaction (Dickey, McKnight \& George, 2008). Findings indicate that high levels of perceived trust between the franchisor and franchisee reduce instances of non-compliance by the franchisee; a combination of trust and honesty also found to contribute to franchisee satisfaction intra-system (Dickey et al, 2007).

Such, there is an imperative in extending the investigation of trust and commitment within a franchising relationship, particularly the application of a trustcommitment model in a long distance franchise system context. Further, the few existing studies in this area lack perspective, and are limited to a single participant focus. Hence, this study applies the trust-commitment model in a long distance 
(international context), examining franchisee' perceptions to attain a deeper insight prior to a necessary movement towards a multi-participant explanatory approach.

\section{Trust}

The relational variable, trust, appears to serve as the mechanism facilitating cooperation and generating relationship commitment (Morgan and Hunt, 1994). Trust occurs when one person can rely on the word and actions of another (Rotter, 1967) and is part of the chemistry facilitating relationship effectively (Inkpen and Birkenshaw, 1994), instilling meaning and value (Madhok, 1995). For one party to trust another, participants in a relationship (i.e. franchisees and franchisors) must feel comfortable with each other (Rodriguez and Wilson, 2002) as trust involves elements of risk and doubt (Currall and Judge, 1995).

\section{Commitment}

Commitment, defined as the continued need to preserve a relationship (Moorman, Zaltman, and Deshpande, 1992), and suggested to develop over time if partners perceive value in the beneficial outcomes of the relationship (Sarkar, Cavusgil, and Evirgen, 1997). Essentially, a franchisee is committed to their franchisor throughout the relationship; a relationship built on the foundation of mutual commitment and trust (Berry and Parasuraman, 1991).

\section{The franchisor-franchisee relationship}

A focul point of the formal control of franchisor-franchisee relationship within agency theory literature is significant (Fama and Jensen, 1983; Shane, 1996; and Stanworth, Price, Purdy, Zafiris, and Gandolfo, 1996). The contractual agreement between participants of a franchise recognised as the formal control, suggested to attain goal congruence and offer the provision of monitoring capability (Eisenhardt, 
1989; Leblebici and Shalley, 1996). At an impersonal transactional level, Pizanti and Lerner (2003) identify this legally binding agreement as a primary aspect necessary for firm growth and survival. However, under the premise of agency theory, such a statement limited as ignorance of the relational complexity of the franchise intrasystem (Pizanti and Lerner, 2003).

As highlighted relational development is an important cornerstone within a dyadic business environment (Baker, Buttery, and Richter-Buttery, 1998). Yau, McFetridge, Chow, Lee, Sin, and Tse (1999) recognise the development of social interactions within the business intra-system, contributing to the achievement of effective management process, ultimately enhancing trust and commitment, contributing to the achievement of effective achievement. The presence of trust and commitment suggested as "cementing the relationship" together (Doherty and Alexander, 2004: p1229).

Therefore, variables explored to inform the research posed within this paper; factors enhancing or detracting from the development of commitment and trust within international franchising relationships (i.e. organisational culture, attitude, passion, respect etc.). The aim of this research is to develop a model for franchising relationships focussing on the relationship between trust and commitment. Other studies have investigated this key relationship but not in an international context or if trust and commitment are key determinants for success or failure.

\section{Methodology and data collection}

The interpretive researcher aims to gain an initial understanding of meaningful social actions, that is, the discovery of how people construct meaning in natural settings (Neuman, 2006). Construction of themes for further testing in an empirical 
context can result (Patton, 2002). Franchisee perceptions were treated in this manner in this study (Hunt, 1990). Therefore, a multiple case study approach was adopted (Yin, 2003; Eisenhardt, 1989b; and Parkhe, 1993). The sample consisted of four major Australian franchise systems, purposively selected based on possessing: (1) both Australian and NZ operations and (2) conduct of business operations within the food-retailing sector. Five franchisees from each system in both the Australian and New Zealand operations were interviewed (refer Table 1) resultant, twenty, in-depth interviews (refer Table 2). Structure interviews were utilised, with a range of probing questions developed around the themes of relational trust and commitment (Carson, Gilmore, Perry, and Gronhaug, 2001). Interviews were recorded and averaged 20 minutes in duration. Transcription of each conversation took place to form a case study base and analysed with NVivo to ensure reliability (LeCompte and Goetz, 1982; Lincoln and Guba, 1985).

The case based approach identified common themes among and across cases, enhancing “analytical generalisation” (Yin, 2003: p32) of contemporary franchising issues within the KMV model. Dominant themes emerged from this process and formed nodes, or specific categories, enabling a more structured understanding of commonalities, the results informing the development of The Franchising Relational Dynamics Model (Figure 2 below). Each element of the model is developed in the following section.

Insert Table $1 \& 2$ here 
Insert figure 2 here

Page 11 of 30 


\section{Findings}

Findings support the commitment-trust framework posed by Morgan and Hunt's (1994). However, perspectives of respondents were polarised. Nevertheless, trust and commitment were universally identified as antecedents for strong and productive relationships. Moreover, franchisees who reported diminished trust and commitment considered exit strategies based on limited personal connection with their franchisor.

Key attributes, such as effective franchisor-franchisee relationships, trust, commitment, goal congruence and organisational culture, linking the Franchising Relational Dynamics model presented in figure 2 form the basis of this discussion.

\section{Effective franchisor-franchisee relationships}

Franchisees expressed “a lot less stressful” business relationship if personal variables were apparent. In particular, the dominant finding of "it is better having a good relationship with them (franchisor) than not", whereby an effective personal relationship had the effect of "fine tuning” the franchising arrangement. When asked about this perception on personal relationships, one franchisee answered,

"I think in any relationship you are going to have disagreements.

We do with our staff, we do with our franchisor, but you need to have that personal touch to heal that afterwards."

This provides for a customised approach to franchising, with relational difficulties overcome due to the presence personalisation within the relationship. Four franchisees stated they did not have an effective personal relationship with their franchisor. These franchisees were either exiting or considering leaving their 
respective systems. Such findings establishing the importance of developing effective personal relationship between participants in any franchise system.

\section{Trust}

One franchisee stated, "There probably would be an element of trust if there was a relationship, but there is no relationship.” This franchisee found it difficult to commit to the business relationship through a lack of trust. In this case trust existed at the beginning of the relationship, however when probed further, the respondent stated "too much at the beginning", in the context of too much trust. Such trust over time slowly depleting, possibly driven by opportunistic actions undertaken by the franchisor, shifting the franchisee' perception to a belief "they don't care".

\section{Commitment}

The nature of the franchise relationship depicts the need for commitment, supported with comments by one franchisee stating, “you've got to be fully committed and your other half has to be fully committed". As the franchise relationship constitutes a business-to-business relationship, formal commitments are necessary, usually in the form of franchise agreements (e.g. both parties possessing financial and legal obligations to each other). All franchisees interviewed possessed such contracts, commitment bound legally and financially. All respondents recognised the legal (and subsequent financial) commitment to the franchise relationship (through the franchise agreement) however outcomes of the research revealed the manifestation of this relationship needed to be personalised Of particular interest, the varying levels of commitment amongst respondents.

Mature franchisees showing less of an interest in remaining fully committed and new franchisees expressing a stronger commitment mindset. One franchisee 
stated when he needed help it was important to know that "they are (franchisor) going to be there for me" in times help is required. . Further, commitment expressed on a personal level enhanced the professional nature of the franchising arrangement. One franchisee explained a situation assisting his commitment to the franchise:

"The previous manager was good at taking it past the manager thing, like when I went up to Auckland he took me out in the boat for the day, we went sailing, we had a few drinks, so it was more a comradely, matey thing."

Thus, franchisors that were able to instil a friendly, positive organisational culture enhanced system trust and commit.

\section{Organisational Culture}

The culture of the franchise also influenced (either positively or negatively) trust in the franchise relationship. One franchisee related this theme as, "an organisation (franchise) is only people at the end of the day", with the nature of both the franchisor and the franchisee identified as influencing the overall relationship stability. Discussion of the different perspectives of franchisors and franchisees as follows in the proceeding subsections.

Nature of the franchisor - This construct focuses on franchisee perceptions of the character of their franchisor. Each franchisee had a unique perception of their franchisee. For example, one franchisee stated,

"People have different views and often it depends on whether the business is successful or not as to what their view of the franchisor is." 
This sentiment was a dominant theme throughout the findings where those suffering in a competitive business environment were generally negative toward their franchisor, as they tended to blame the franchisor for their misfortune. However, it is still necessary in the franchising relationship for the franchisor "to deliver...the personality behind it". Thus, analysis took place in the context of the relevant franchise system identified below.

Franchise system A received a strong positive perception of their behaviour from all franchisees. Out of the four franchise systems, this franchise seemed to have the most positive perception. When asked about the nature of her franchisor, franchisee A1 stated that,

"They always talk to you and address you very nicely, and their attitude is 'it's not a problem'."

She also perceived her franchisor as having a focus "beyond just money" where the franchisor's nature was,

"About seeing people succeed and not just the money behind it, and that's where I see this one (as) different."

The franchisors in franchise A were also "very professional, very organised, (and) very open" and if a franchisee "knocked on their door...they've always been there for (them)." It was also important to franchisees that the franchisor possessed a level of industry experience, which helped promote a positive perception, knowing that they (the franchisee) are not "coming in blind". Therefore, the positive perception of the franchisor is a common theme in franchise system A.

Franchise system $B$ formed a perception of their franchisor as less positive than those identified in franchise system A. This was due to a majority of franchisee 
having developed negative experiences that tainted their perception of the nature of their franchisor. In the initial stages of the relationship, franchisees found the franchisor to be "very intimidating ... (and)...very bullying”.

Franchise system $C$ had franchisees with mixed opinions towards their franchisor, where one franchisee had a negative "first impression" because of an incident during one of the first training sessions. The franchisee voiced his contempt for the franchisor's behaviour (the franchisor ignored a group of newly inducted franchisees at an initial training day). This franchisor chose not to introduce or welcome any of the new franchisees. This lack of emotional involvement by the franchisor resulted in a negative perception of the system culture as perceived by franchisees.

Franchise system $D$ received positive ratings from almost all NZ and Australian franchisees. However, the two franchisees expressed negative perceptions of the nature of their franchisor from similar incidents. The incidents involved the franchisor conducting themselves in a manner that was off-putting for the franchisees. These actions resulted in negative perceptions, which were difficult to reverse. One franchisee stated that,

“Ever since then, that guy (the franchisor) I've had absolutely no time for. I've never missed an opportunity to slag him off; I never miss an opportunity to tell that story to whomever."

The franchisee described the instance as the franchisor abusing his authority by embarrassing a member of the franchisees’ staff based on a trivial matter.

Nature of the franchisee - It is clear that the franchisees interviewed have “different personalities and people have different ways of doing things" and every 
franchisee had a different perception on how they conducted themselves in the franchising environment. As conceptualised in the Franchising Relational Dynamics model (figure 1), four elements influenced the nature of the franchisee: attitude, passion, dependence, and respect.

One franchisees attitude was that of always trying to "stay positive" whereas another "tend(ed) to abide by the rules (and) play the game". A dominant theme developed from the interviews was franchisees ability to choose their attitude toward the relationship with their franchisor,

"I think it helps to like them, I think you make yourself like people if you're going to shovel out some money don't you, because you want it to work."

Franchisees that were "willing to be open-minded" in any situation provided opportunities to resolve conflict within the relationship that they recognised will always go "through ups and downs" and can sometimes be a "love/hate relationship". This positive attitude overcame many structural deficiencies intra-system and external market forces that could manifest in low sales/profit.

Passion was identified as an attribute associated with the nature of the franchisee and this directly contributed to an effective franchise relationship. A passionate franchisee was usually more willing to focus on the 'bigger' picture as opposed to the small or trivial issues. When asked about passion, one franchisee said,

"Yeah I'm a baker by trade so probably baking's a passion for me, rather than just a lifestyle. Like anyone can buy this franchise, do a ten week course and then they're a baker. But for me it's a passion. A lot of people at the top have been there for 30 years so their passion is bread as well so I feel that anything we do impacts the business as well.” 
Passion expressed by the franchisee and/or the franchisor had a positive influence on relational stability in that it provided motivation to carry out what was described as "the daily grind" of running a labour-intensive business.

A multiple-unit franchisee expressed his opinion on this matter where his passion not only influenced the relationship with his franchisor but the relationship with his staff, something seen as essential for successful business operations:

"I've been doing this for 5...years and I do it with passion still and I have 80 people who are extremely passionate about it as well and they follow my lead."

Each franchisee varied their level of dependence on their franchisor, an element associated with the nature of each individual franchisee. That is, one franchisee stated they “don't actually like depending on people”. This particular franchisee lacked trust and commitment within her franchising relationship. Another independent franchisee stated,

"I don't have any problems with anyone, I say what I think, they can say what they think to me you know, everyone's entitled to their opinion."

A strong theme from these findings indicated that every franchisee possessed different levels of dependence on their franchisor but franchisees new to the system were generally more dependent on the franchisor than more mature franchisees. This theme exists throughout franchising research. However, regardless of the time spent in a franchise, an important aspect necessary in the franchising relationship identified in this research included the perception that franchisees being "strong enough to advocate (themselves)" would avoid being “dictate(d)" to by the franchisor. However, one franchisee believed "that the franchisor has the right advice for me and 
whatever advice they give me I just do it.” This statement highlights a link between dependence and trust with the franchisor.

Respect also significantly influenced the relationship stability. One franchisee realised that respect in her relationship improved her performance and stated,

"I think you do better for them because you want to do well for them as much as yourself because you've got that respect."

Another franchisee developed an opposite perspective, due to a lack of respect in her relationship. She did not want to perform for the franchisor based on the franchisor's prior behaviour. Therefore, the actions of the franchisor could and should foster mutual respect. Alternatively, where little or no respect was apparent, generally there were negative perceptions toward the franchisor.

\section{Goal Congruence}

The franchise relationship is described as asymmetric (characterised by power imbalance and one-way communication) giving rise to opportunistic behaviour by both parties to the franchise agreement, from their own agendas (Lafontaine \& Shalley, 1997). In this context, franchisees were aware of the franchisor's vision and its impact on the relationship. Nevertheless, a selection of franchisees stated their personal agenda was 'in line' with their franchisor. For example, the vision of one franchisee 'matched perfectly' that of the franchisor. The remaining franchisees adapted their goals to that of the franchisor to achieve goal congruence with one franchisee having "aligned" her vision with that of the franchisor. Though this adjustment did not compromise any personal values, franchisees realised, from a business perspective, the necessity to "read off the same page" as their franchisor, thereby reducing the incidence of opportunistic behaviour. 
Evident from the data was a sharing of common values and goals but with an element of self-interest giving rise to opportunistic behaviour. No respondents were willing to discuss particular acts regarding this type of behaviour, but did identify other franchisees acting opportunistically. These instances included serving half-portions of food, buying cheaper products from alternative sources (than the franchisor), conducting local advertising campaigns without franchisor permission, and making unauthorised additions to the standardised menu. These acts of opportunism involved doing "something outside the acceptable norms of... (the) franchise system." Nevertheless, franchisees were generally allowed to adapt the standards as one respondent stated, “...you run it past them (the franchisor) and nine times out of ten, they'll say sure.” Some franchisees also freely accepted opportunistic acts performed by the franchisor. One franchisee stated,

"(The franchisor) makes changes and they stick to it. There's a certain amount that they dictate to us, I kind of anticipate that that goes with the turf."

Therefore, franchisees appeared to be well aware of situations where an element of opportunistic behaviour existed. However, continued opportunistic acts damaged the stability of the franchise relationship and negatively affected franchisorfranchisee goal congruence.

In summary, Morgan and Hunt's (1994) commitment-trust theory appears consistent and relevant in the franchising relationship. Franchisees desire and appreciate the need for an effective relationship with their franchisor; a relationship highlighted by the presence of trust and commitment. However, the model does not fully explain some aspects of the franchise relationship. Discussion of implications takes place in the next section. 


\section{Implications}

The current study provides both franchisors and franchisees a more detailed understanding of franchise relational dynamics. The Franchise Relational Dynamics model presented in Figure 2 indicates a more complex set of variables surrounding the dynamics of trust and commitment and its effects on the franchising relationship. It is of great importance in the franchising arrangement, from the franchisee's perspective, to develop a more positive personal relationship with an increase in distance through international arrangements. While franchisors of transnational systems understand and benefit from these types of relationships they should not be driven purely by economic and material benefits (Rodriguez and Wilson, 2002), but be influenced by social exchanges. Thus, trust and commitment form the basis of positive franchise relationships, through ongoing and effective communication, but are preceded by the nature of the franchisee, franchisor personalities, and goal congruence.

Essential to the relationship is continued personalised representation toward franchisees, even across borders. This managerial process is driven by organisational culture where the nature and motivations of franchisors impact on the perceived culture of the franchise. Out of the four franchise systems, franchise system A was deemed to have the most positive organisational culture: largely due to the presence of "friendly" and "professional" people within the organisation. This attitude was consistent in both the Australian and New Zealand operations.

Critical to franchise systems organisational culture was the need for franchisees to understand the nature of the franchisor. This understanding was gained through direct experience and observation of the franchisor (with single experiences often leaving a long-term impression). Of the twenty franchisees interviewed, the more mature franchisees were generally more appreciative of the franchisor. More 
mature franchisees were cognisant and appreciative of relational challenges associated with the ongoing management of large franchise organisations. By committing to the franchising relationship, franchisees receive the associated benefits of an effective personal relationship with their franchisor that has a positive impact on the daily operations. Industry experience of the franchisor was important in this context as it contributed to the maturity of the organisation as a whole. As a result, the emphasis changed from transaction exchanges to a more personal relationship. This provided opportunities for franchisees to mediate potential conflict intra-system by focussing on super-ordinate goals thereby achieving goal congruence. This attitude resulted in more efficient, productive and effective operations within the franchise systems.

\section{Limitations}

This study highlights consistent and personalised communicative practices between franchise parties to develop trust and commitment within a long distance relationship. Limitations are evident based on the concentration on the franchisee, with further insight requiring investigation of both parties. As the franchising relationship is dyadic (although considered asymmetrical), consideration of the franchisor perspective is necessary in order to develop a more generalisable model. The exploratory nature of the research process also provides a relevant trajectory to develop and test an appropriate instrument. Nevertheless, this paper provides a strong foundation whereby contemporary relational issues have been explored prompting future research to extend the implications identified. 


\section{Conclusion and future directions}

This paper explores franchisee perceptions of the franchise relationship utilising the Morgan \& Hunt (1994) trust-commitment model. Application of this structure formed the basis of a Franchising Relational Dynamics conceptual model that more accurately explains trust and commitment within the franchise dyad. The interactive franchisor-franchisee relationship represented in the Franchising Relational Dynamics model shows that initial formation and subsequent continuance of the relationship (through first impressions, ongoing experiences and the level of emotional involvement as defined in the model) has a significant impact, most notably long distance, where isolation is most apparent. Further, attitude, passion, dependence and respect, impact significantly on the franchise relationship with these attributes manifested (positively or negatively) through organisational culture. Improvement in a franchisee's trust and commitment to the franchise system potentially avoids relational conflict, and provides an antecedent to greater franchisee compliance/acceptance to organisational norms and structure. 


\section{References}

Baker, M., Buttery, E., and Richter-Buttery, E. (1998). "Relationship marketing in three dimensions." Journal of Interactive Marketing 12(4): 47-62.

Berndt, A. (2009). "Franchisee satisfaction among food franchisees: an exploratory study." Southern African Business Review Volume 13(1): 1-20.

Berry, L., and Parasuraman, A. (1991). "Marketing Services." New York: The Free Press.

Carson, D., Gilmore, A., Perry, C., \& Gronhaug, K. (2001). "Qualitative Market Research." London: Sage Publications.

Castrogiovanni, G.J., Combs, J.G. \& Justis, R.T. (2006). Resource Scarcity and Agency Theory Predictions Concerning the Continued Use of Franchising in Multi-outlet Networks. Journal of Small Business Management, 44(1), 27

Chiou, J., Hsieh, C. \& Yang, C. (2004). The Effect of Franchisors' Communication, Service Assistance, and Competitive Advantage on Franchisees' Intentions to Remain in a Franchise System. Journal of Small Business Management, 42(1): 19-36.

Currall, S., \& Judge, T. (1995). "Measuring trust between organizational boundary role persons." Organisational Behaviour and Human Decisions Sciences 64(2): 151-170.

Dant, R., \& Gundlach, G. (1999). "The challenges of autonomy and dependence in franchised channels of distribution." Journal of Business Venturing 14(1): 3567.

Davies, M.A.P., Lassar, W., Manolis, C., Prince, M. \& Winsor, R.D. (2009). A model of trust and compliance in franchise relationships. Journal of Business Venturing, 1-20.

Dickey, M.H., McKnight, D.H. \& George, J. F. (2008). "The role of trust in franchise organizations." International Journal of Organizational Analysis 15(3): 251282.

Doherty, A., \& Alexander, N (2004). " Relationship development in international retail franchising." European Journal of Marketing 38(9): 1215-1235.

Eisenhardt, K. (1989). "Agency Theory: an assessment and review." Academy of Management Review 14: 532-550.

Etgar, M. (1978). "Differences in the use of manufacturer power in conventional and contractual channels." Journal of Retailing 55(1): 61-78.

Fama, E., \& Jensen, M (1983). "Agency problems and residual claims." Journal of Law and Economics 26(2): 327-350.

Frazer, L., Weaven, S., \& Wright, O (2006). " Franchising Australia 2006." Brisbane, Griffith University.

Frazer, L., Weaven, S., \& Wright, O (2008). " Franchising Australia 2008." Brisbane: APCFE, Griffith University.

Frazer, L., Weaven, S., \& Bodey, K (2010). " Franchising Australia 2010." Brisbane: APCFE, Griffith University.

Harmon, T.R. \& Griffiths, M.A. (2008). Franchise perceived relationship value. Journal of Business and Industrial Marketing, 23(4): 256-263.

Hunt, S. (1973). “The Trend Toward Company-Operated Units in Franchise Chains”. Journal of Retailing, 49 (Summer), 3-12.

Hunt, S. (1990). "Commentary on an Emperical Investigation of a General Theory of Marketing Ethics." Journal of Consumer Research 18(1): 32-44. 
Inkpen, A., \& Birkenshaw, J. (1994). "International joint ventures and performance: an interorganisational perspective." International Business Review 3(3): 201217.

Jean, R., Sinkovics, R.R. \& Kim, D. (2010). Drivers and Performance Outcomes of Relationship Learning for Suppliers in Cross Border Customer-Supplier Relationships: The Role of Communication Culture. Journal of International Marketing, 18(1): 63-85.

Lafontaine, F., \& Slade, M. (1997). "Retail Contracting: Theory and practice." The Journal of Industrial Economics 45: 1-25.

Leliaert, P.J.C., Candries, W. \& Timlans, R. (2003). Identifying and managing IC: a new classification. Journal of Intellectual Capital, 4(2): 202-214, In Watson, A., Stanworth, J., Healeas, S., Purdy, D., Stanworth, C. (2005). "Retail franchising: an intellectual capital perspective." Journal of Retailing and Consumer Services 12: 25-34.

Leblebici, H., \& Shalley, C (1996). "The organisation of relational contracts: The allocation of rights in franchising." Journal of Business Venturing 11: 403418.

LeCompte, M., and Goetz, J (1982). "Problems of reliability and validity in ethnographic research." Review of Educational Research 52(1): 30-60.

Lincoln, Y., and Guba, E (1985). "Naturalistic Inquiry." Newbury Park: Sage.

Madhok, A. (1995). "Revisiting multinational firms' tolerance for joint ventures: a trust-based approach." Journal of International Business Studies 26(1): 117137.

Moorman, C., Zaltman, G., and Deshpande, R. (1992). "Relationships between providers and users of merkating research: the dynamics of trust within and between organisations." Journal of Marketing Research 29(3): 314-329.

Morgan, R., \& Hunt, S (1994). "The commitment-trust theory of relationship marketing." Journal of Marketing 58(3): 20-38.

Nathan, G. (2000). "Profitable Partnerships." Brisbane: Nathans Corporate Psychology.

Neuman, W. (2006). "Social Research Methods: Qualitative and Quantitative Approaches.". (6th ed.), Boston: Pearson.

Parkhe, A. (1993). "Messy' Research, Methodological Predispositions and Theory Development in International Joint Ventures." Academy of Management Review 18(2): 227-268.

Patton, M. (2002). Qualitative Research and Evaluation Methods (3rd ed.). Thousand Oaks: Sage Publications.

Pizanti, I., and Lerner, M (2003). "Examining control and autonomy in the franchisorfranchisee relationship." International Small Business Journal 21(2): 131-159.

Quinn, B., \& Doherty, A (2000). "Power and control in international retail franchising." International Marketing Review 17(4): 354-372.

Rodriquez, C., \& Wilson, D (2002). "Relationship bonding and trust as a foundation for commitment in U.S. - Mexican strategic alliances: a structural equation modelling approach." Journal of International Marketing 10(4): 53-76.

Sarkar, S., Cavusgil, T., \& Evirgen, C. (1997). "A commitment-trust mediated framework of international collaborative venture performance" in Cooperative Strategies." North American Perspectives, Beamish, P., \& Killing, J., eds. San Francisco: New Lexington Press: 255-285. 
Shane, S. (1996). "Hybrid organizational arrangements and their implications for firm growth and survival: A study of new franchisors." Academy of Management Journal 39(1): 216-234.

Spinelli, S., \& Birley, S (1996). "Toward a theory of conflict in the franchise system." Journal of Business Venturing 11(5): 329-342.

Stanworth, J., Price, S., Purdy, D., Zafiris, N., and Gandolfo, A (1996). " Business format franchising: innovation and creativity or replication and conformity." Franchising Research: An International Journal 1(2): 29-39.

Stern, L., \& Reve, T (1980). "Distribution channels as political economies: a framework for comparative analysis." Journal of Marketing Research 44(3): 52-64.

Strutton, D., Pelton, L., \& Lumpkin, J. (1995). "Psychological climate in franchise system channels and franchisor-franchisee solidarity." Journal of Business Research 34(2): 81-91.

Webster, F. (1992). "The changing role of marketing in the corporation." Journal of Marketing Research 56(4): 1-17.

Watson, A., Stanworth, J., Healeas, S., Purdy, D., Stanworth, C. (2005). "Retail franchising: an intellectual capital perspective." Journal of Retailing and Consumer Services 12: 25-34.

Weaven, S., Frazer, L. \& Giddings, J. (2010). New perspectives on the causes of franchising conflict in Australia. Asia Pacific Journal of Marketing and Logistics, 22(2): 135-155.

Yau, O. H.M., McFetridge, P. R., Chow, R. P. M., Lee, J. S.Y., Sin, L. Y.M., Tse, Alan C.B. (1999). Is Relationship Marketing for Everyone? European Journal of Marketing, 34(1):111-1127.

Yin, R.K. (2003). Case Study Research, $3^{\text {rd }}$ Eds, London: Sage Publications. 


\section{Table 1: Description of franchise systems}

Franchise A

Franchise B

Franchise C

Franchise D
This franchise was founded in 1989 in Australia. The two founders still have an active part in the leadership of the now international company. This franchise first expanded internationally into New Zealand through a master franchising agreement in 2005. It now boasts an international portfolio of over 170 stores across Australia and New Zealand.

This franchise is a well-established business that has seen huge growth since its inception in 1975. During the 1980s as the franchise expanded through Australia it changed its brand to adopt a stronger Australian identity. A public offering in the 1990s saw the franchise chain grow from 51 stores to currently having over 300 stores across Australia and NZ.

The first franchised store in this system commenced operation in 1991. Three years later this franchise issued a master franchise license to cover the NZ market. The arrangement was severed in 1999 resulting in the dissolution of the NZ master franchise rights and a direct franchisee/franchisor relationship employed. There are currently over 45 stores in Australia and over 20 stores throughout NZ.

Originating in Canada, the concept was refined by a local Australian company, opening the first store in the QLD region in 1989. Five years later saw the expansion into the NZ market under the same local Australian company which today has control of over 150 Australian stores and 36 NZ outlets. 
Table 2: Description of Interviewees

\begin{tabular}{|c|c|c|c|c|c|}
\hline Country & Code & Gender & $\begin{array}{l}\text { Unit in same } \\
\text { city as head } \\
\text { office }\end{array}$ & $\begin{array}{l}\text { Number of } \\
\text { units owned }\end{array}$ & $\begin{array}{l}\text { Time in current } \\
\text { franchise }\end{array}$ \\
\hline \multirow[t]{10}{*}{ New Zealand } & A1 & Female & No & 1 & 1 year \\
\hline & A2 & Male & No & 1 & Less than 1 month \\
\hline & B1 & Male & No & 1 & 9 years \\
\hline & B2 & Male & No & 1 & 8 years \\
\hline & B3 & Male & No & 1 & 8 years \\
\hline & $\mathrm{C} 1$ & Male & No & 1 & 3 years \\
\hline & $\mathrm{C} 2$ & Male & No & 1 & Less than 1 month \\
\hline & C3 & Female & No & 1 & 1 year \\
\hline & D1 & Female & No & 1 & 2.5 years \\
\hline & D2 & Male & No & 3 & 8.5 years \\
\hline \multirow[t]{10}{*}{ Australia } & $\mathrm{A} 3$ & Male & Yes & 3 & 5 years \\
\hline & A4 & Female & Yes & 1 & Less than 1 month \\
\hline & A5 & Male & Yes & 2 & 6 years \\
\hline & B4 & Male & Yes & 1 & Less than 1 month \\
\hline & B5 & Male & Yes & 1 & 2 years \\
\hline & $\mathrm{C} 4$ & Female & No & 1 & 0.5 years \\
\hline & C5 & Male & No & 1 & 1.5 years \\
\hline & D3 & Male & No & 3 & 8 years \\
\hline & D4 & Female & No & 1 & 3 years \\
\hline & D5 & Male & No & 1 & 5 years \\
\hline
\end{tabular}

Source: Developed for this research 
Figure 2: The Franchising Relational Dynamics Model

Source: Developed for this research following convergent interviews with franchisees

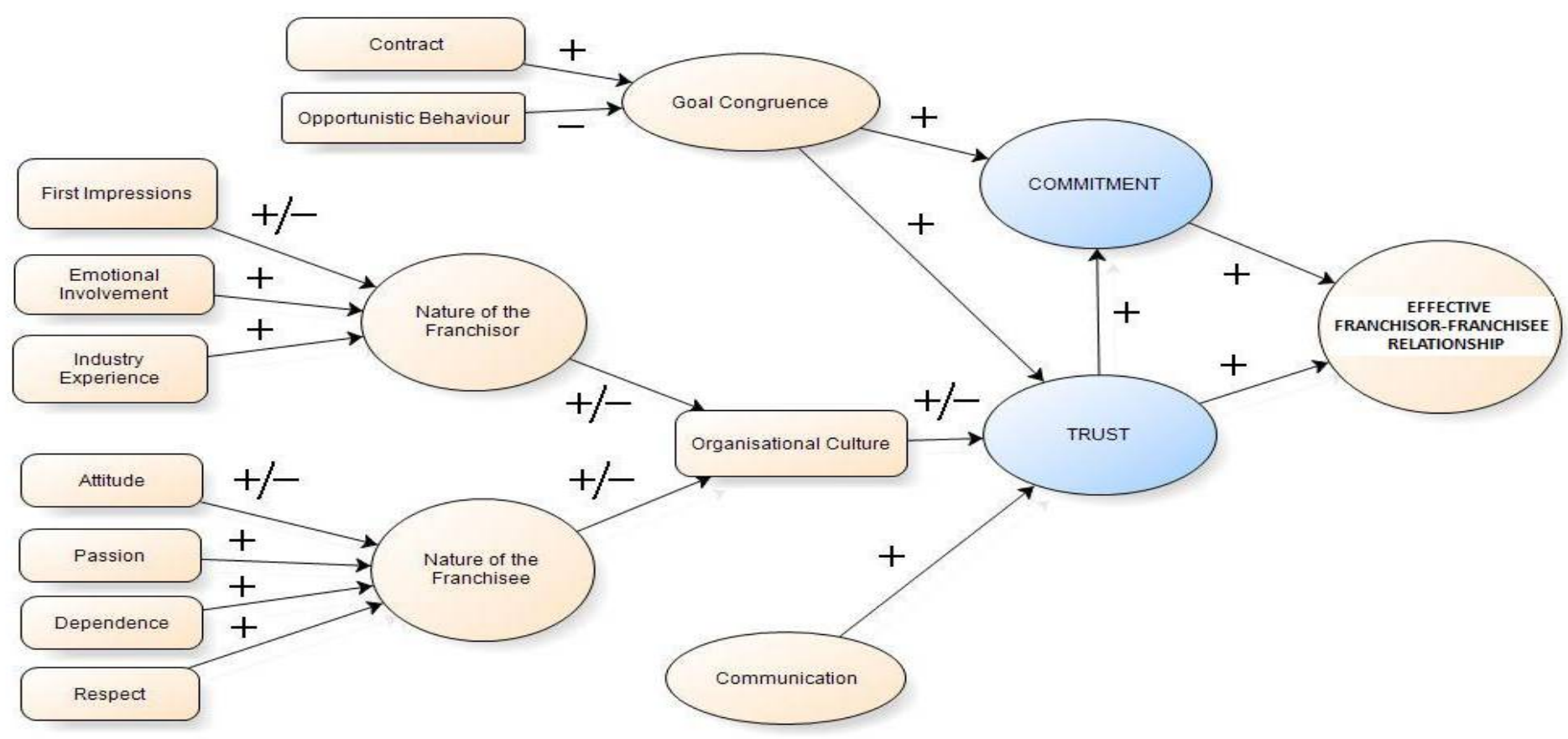


